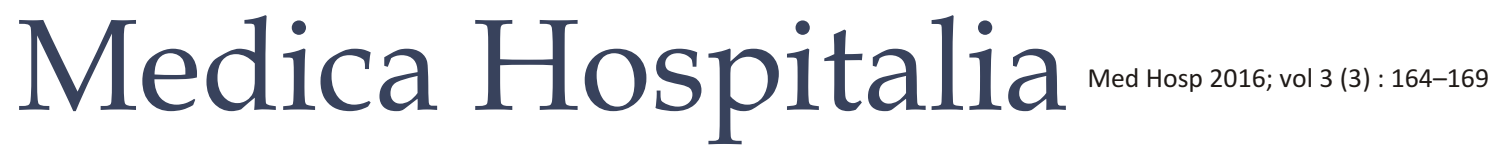

Original Article

\section{Pola Kuman dan Sensitivitas Terhadap Antibiotik Pasien Abses Leher Dalam di RSUP Dr. Kariadi Semarang (April 2012 - April 2015)}

\author{
Shinta Devi Aguslia, Farokah \\ Departemen IKTHT-KL FK UNDIP/ SMF KTHT-KL RSUP Dr. Kariadi Semarang
}

\begin{abstract}
Abstrak
Latar belakang : Abses leher dalam atau deep neck abscess adalah abses yang terbentuk didalam ruang potensial leher dalam karena proses infeksi atau benda asing sebagai akibat perluasan infeksi dari dari gigi, mulut, tenggorok, sinus paranasal, telinga tengah dan leher. Tujuan: Mengetahui gambaran pola kuman dan sensitivitas terhadap antibiotik pasien abses leher dalam, April 2012 sampai April 2015 di RSUP Dr. Kariadi Semarang.

Metode : Studi deskriptif observasional di bagian rawat inap THTKL RSUP Dr. Kariadi Semarang berdasarkan rekam medis penderita abses leher dalam, April 2012 - April 2015 di RSUP Dr. Kariadi Semarang.

Hasil : Sebanyak 54 kasus abses leher dalam, diagnosis terbanyak adalah abses submandibula 46 kasus $(85,1 \%)$, usia terbanyak adalah 41-50 tahun sebesar 13 kasus (24\%). Hasil kultur terbanyak adalah Staphylococcus aureus 8 kasus (14,8\%).

Simpulan : Hasil kultur terbanyak Staphylococcus aureus 14,8\% dan sensitif terhadap antibiotik meropenem, dan diikuti amikasin, cefoxitin dan gentamisin serta kombinasi ampicillin sulbactam dengan ciprofloksasin.
\end{abstract}

Kata kunci : Abses leher dalam, pola kuman, sensitivitas terhadap antibiotik.

\section{Bacteriae pattern and antibiotic sensitivity of deep neck abscess in Dr. Kariadi Hospital Semarang (April 2012 - April 2015)}

\begin{abstract}
Background : The neck abscess or deep neck abscess is an abscess formed in the potential space in the neck because the process of infection or foreign body as a result of the expansion of the infection of the teeth, mouth, throat, paranasal sinuses, middle ear and neck. The aims: the pattern overview of germs and antiiotic sensitivity of the deep neck abscess April 2012 to April 2015 in Dr. Kariadi Hospital, Semarang.

Methods : Descriptive observational study in the patient ENT-KL Dr. Kariadi Hospital, Semarang on medical records of patients with the deep neck abscess in the period April 2012-April 2015.

Results: A total of 54 cases of deep neck abscess, diagnosis is the most submandibular abscess 46 cases $(85.1 \%)$, the highest age range is $41-50$ years 13 cases (24\%). Most cultures are Staphylococcus aureus 8 cases (14.8\%).

Conclusion : The most cultures are Staphylococcus aureus and $14.8 \%$ sensitive to the antibiotic meropenemand than followed are amikacin, cefoxitin, gentamicin and ampicillin sulbactam combination with ciprofloxacin.
\end{abstract}

Keywords : Deep neck abscess, Bacteria pattern, Antibiotic sensitivity. 


\section{PENDAHULUAN}

Abses leher dalam atau deep neck abscess adalah kumpulan nanah yang terakumulasi di didalam ruang potensial leher dalam karena proses infeksi atau benda asing dan reaksi perlindungan jaringan untuk mencegah penyebaran dan perluasan infeksi ke bagian lain dari tubuh. Abses leher dalam terbentuk di dalam ruang potensial di antara fasia leher dalam sebagai akibat perluasan infeksi dari gigi, mulut, tenggorok, sinus paranasal, telinga tengah dan leher. Sumber infeksi yang paling sering berasal dari gigi dan saluran aerodigestif. Gejala dan tanda klinik yang ditemukan sesuai ruang potensial yang terlibat., ${ }^{1,3}$ Komplikasi yang berbahaya dan sulit untuk mengatasi adalah apabila telah terjadi sepsis. Selain drainase abses, pemberian antibiotik sesuai kultur merupakan penatalaksanaan abses leher dalam, namun membutuhkan beberapa hari untuk memperoleh hasil kultur sehingga sering digunakan terapi antibiotik empiris sebelum hasil kultur tersedia. ${ }^{4}$

Tujuan penulisan ini adalah untuk mengetahui pola kuman terhadap antibiotik abses leher dalam di RSUP Dr Kariadi Semarang sehingga didapatkan jenis antibiotik yang sesuai sebagai bukti empiris.

\section{METODE}

Penelitian ini dilakukan dengan metode diskriptif observasional. Sampel penelitian diambil dari catatan medik penderita abses leher dalam yang dirawat di bangsal rawat inap IK THT-KL RSUP Dr. Kariadi Semarang periode April 2012 sampai April 2015. Kriteria eksklusi adalah penderita dengan data yang tidak lengkap.

\section{HASIL}

Penelitian ini didapatkan 54 kasus abses leher dalam dirawat di bangsal rawat inap IK THT-KL RSUP Dr. Kariadi Semarang selama April 2012 sampai April 2015. Terdiri dari laki-laki 37 orang $(68,5 \%)$, perempuan 17 orang $(31,5 \%)$. Rentang usia terbanyak adalah usia 41 50 tahun 13 orang ( $24 \%$ ). Profil usia penderita abses leher dalam dapat dilihat pada tabel 1 .

\section{PEMBAHASAN}

Hasil penelitian ini didapatkan, untuk jenis kelamin lakilaki dengan perempuan 2:1, sesuai dengan penelitian Yang dkk, pada 100 kasus abses leher dalam yang diteliti mulai April 2001 - Oktober 2006. Usia yang terbanyak antara 41-50 tahun sebesar 24\%. Sesuai peneltian Scottt dkk dan Jeffrey dkk (2005) terbanyak pada usia dewasa antara $40-50$ tahun. $5,6,7$

Etiologi abses leher dalam yang paling sering ditemukan pada penelitian ini adalah odontogen

\begin{tabular}{lcc|}
\hline \multicolumn{3}{l}{ PABEI 1} \\
\multicolumn{3}{l}{ Profil usia pada penderita abses leher dalam } \\
Usia & Jumlah & Prosentase \\
\hline 0 - 10 tahun & 2 & $3,7 \%$ \\
11 - 20 tahun & 2 & $3,7 \%$ \\
21 - 30 tahun & 8 & $14,8 \%$ \\
31 - 40 tahun & 9 & $16,7 \%$ \\
41 - 50 tahun & 13 & $24 \%$ \\
51 - 60 tahun & 12 & $22,2 \%$ \\
61 - 70 tahun & 6 & $11,1 \%$ \\
71 - 80 tahun & 2 & $3,7 \%$ \\
\hline
\end{tabular}

\section{TABEL 2}

Diagnosis berdasarkan lokasi abses

\begin{tabular}{lcc} 
Jenis abses & Jumlah & Prosentase \\
\hline Abses peritonsil & 4 & $7,4 \%$ \\
Abses submandibula & 46 & $85,1 \%$ \\
Abses parafaring & 1 & $1,9 \%$ \\
Abses retrofaring & 2 & $3,7 \%$ \\
Abses sublingualis & 1 & $1,9 \%$ \\
\hline
\end{tabular}

\section{TABEL 3}

Etiologi abses leher dalam

\begin{tabular}{lcc} 
Etiologi & Jumlah & Prosentase \\
\hline Odontogenik & 37 & $68,5 \%$ \\
Saluran aerodigestif & 4 & $7,4 \%$ \\
Tidak diketahui & 13 & $24 \%$ \\
\hline
\end{tabular}

sebanyak 68,5\%. Menurut Bailey BJ (2006) bahwa sumber infeksi biasanya berasal dari odontogenik, saluran aerodigestif atas atau otogenik. ${ }^{4}$ Marina dkk (2009) mengemukakan bahwa fokal infeksi yang paling sering menyebabkan abses leher dalam adalah infeksi dari gigi (37\%) dan adenotonsilar (20\%). ${ }^{7}$ Etiologi terbanyak biasanya berasal dari infeksi gigi, terutama M2 dan M3 rahang bawah. Hal ini disebabkan adanya hubungan antara akar gigi tersebut melampaui ke bagian bawah tempat insersi otot milohioid pada mandibula, yang langsung berbatasan dengan ruang submaksilaris. Abses 


\begin{tabular}{|lcc|}
\hline $\begin{array}{l}\text { Penatalaksanaan abses leher dalam } \\
\text { Penatalaksanaan }\end{array}$ & Jumlah & Prosentase \\
\hline Antibiotik & 3 & $5,6 \%$ \\
$\begin{array}{l}\text { Antibiotik + insisi draenase } \\
\begin{array}{l}\text { Antibiotik + insisi } \\
+ \text { draenase + trakhetomi }\end{array}\end{array}$ & 45 & $83,3 \%$ \\
$\begin{array}{l}\text { Antibiotik + tonsilektomi } \\
\text { Antibiotik + insisi } \\
+ \text { draenase + tonsilektomi }\end{array}$ & 3 & $3,7 \%$ \\
\hline
\end{tabular}

\begin{tabular}{lcc}
$\begin{array}{l}\text { TABE } \begin{array}{l}\text { Hasil kultur pus } \\
\text { Kultur }\end{array} \\
\text { Jumlah }\end{array}$ & Prosentase \\
\hline Streptococcus pneumoniae & 2 & $3,7 \%$ \\
Streptococcus aureus & 3 & $5,6 \%$ \\
Streptococcus $\alpha$ hemolitikus & 1 & $1,9 \%$ \\
Klebsiella sp & 5 & $9,3 \%$ \\
Staphylococcus aureus & 8 & $14,8 \%$ \\
E colli & 1 & $1,9 \%$ \\
Borrelia Sp & 1 & $1,9 \%$ \\
Anterobacter Sp & 1 & $1,9 \%$ \\
Pseudomonas auriginosa & 4 & $7,4 \%$ \\
Tidak terdapat pertumbuhan & 15 & $28,4 \%$ \\
Kuman tidak diperiksa & 13 & $24,1 \%$ \\
& & \\
\hline
\end{tabular}

pada akar gigi tersebut dapat menembus korteks lingualis yang relatif tipis di bawah garis insersi otot milohioid dan menginfeksi ruang submaksilaris, kemudian dapat meluas ke ruang sublingualis. ${ }^{7,8}$

Berdasarkan diagnosis abses leher dalam meliputi abses peritonsil, abses submandibula, abses parafaring, abses retrofaring dan abses sublingualis. Hasil penelitian adalah abses submandibula sebesar $85,1 \%$ diikuti abses peritonsil $7,4 \%$ seperti tabel 2 . Penelitian sebelumnya menurut Yang dkk, terbanyak adalah abses submandibula sebesar 35\%, lebih dari 1 abses $29 \%$, abses infrahyoid 26\%, abses parafaring 20\%. ${ }^{5}$ Sedangkan Yellon dan Bluestone (1996) dan penelitian Frans (2006) yang mengemukakan terbanyak adalah abses peritonsilar. ${ }^{9,10}$

Penyakit sistemik yang menyertai terbanyak adalah Diabetes mellitus sebanyak 13 orang (24\%),
Hipertensi sebanyak 3 orang $(5,6 \%)$, penyakit jantung 1 orang $(1,9 \%)$, tanpa penyakit penyerta sebanyak 17 orang $(31,5 \%)$. Lama perawatan diperoleh $<7$ hari sebanyak 51 orang $(94,4 \%), \geq 7$ hari sebanyak 3 orang $(5,6 \%)$. Kondisi saat pulang didapatkan penderita yang sembuh 52 orang $(96,2 \%)$, dan meninggal 2 orang $(3,7 \%)$. Terlambatnya diagnosis atau terapi yang tidak adekuat atau tidak sesuai dapat menyebabkan komplikasi seperti mediastinitis, yang angka mortalitasnya mencapai 40\%.3,4,11 Mengingat penderita sebagian besar dewasa sehingga penanganan yang tidak tepat dapat mempengaruhi produktifitas kerja dan gangguan kualitas hidup.

Tatalaksana yang telah dilakukan pada penelitian ini adalah berupa medikamentosa, insisi drainase dan beberapa kasus dilakukan tonsilektomi dan trakeostomi sesuai indikasi. ${ }^{12}$

Hasil kultur bakteri yang tersering adalah Staphylococcus aureus 14,8\% diikuti Klebsiella sp sebanyak $9,3 \%$, Pseudomonas auriginosa 7,4\%, Streptococcus aureus 5,6\%, Streptococcus pneumonia 3,7\%, E. Colli sebanyak 1,9\%, Borrelia sp 1,9\% dan Anterobacter sp 1,9\%. Hasil berbeda penelitian yang dilakukan Nagendra dkk (2012) menyatakan bahwa hasil kultur terbanyak adalah Streptococcus viridans $64 \%$ diikuti Staphylococcus aureus $13 \% .^{10}$ Jeffrey dkk, (2005) mengemukakan bahwa bakteri gram positif aerob yang tersering dari abses leher dalam adalah golongan Streptococcus sedangkan gram negatif aerob adalah Klebsiella $s p$ dan Neisseria sp, bakteri anaerob terbanyak Peptostreptococcus dan Bacteroides sp. ${ }^{6}$ Kesimpulan bahwa bakteri terbanyak pada kultur abses leher dalam adalah golongan coccus. Kuman anaerob jarang terdeteksi pada penelitian ini karena tidak adanya permintaan yang spesifik untuk kuman anaerob kepada laboratorium mikrobiologi, cara pengambilan kultur dan transport sampel kultur yang kurang tepat sehingga mengakibatkan kuman telah mati sebelum diperiksa. ${ }^{13,14,15}$ Penelitian ini terdapat penderita yang tidak terdeteksi bakteri dari kultur sebanyak 28,4\% karena sebelumnya telah mendapatkan terapi antibiotik di puskesmas atau rumah sakit daerah.

Pemberian antibiotik pada penderita abses leher dalam idealnya sesuai dengan hasil kultur pus, tetapi hal ini memakan waktu lama untuk mengetahui hasil kultur dan tes sensitifitas sehingga umumnya terapi antibiotik yang diberikan berdasarkan empiris sebelum keluar hasil kultur. Pemberian antibiotik abses leher dalam di RSUP Dr. Kariadi, sebelum keluar hasil kultur diberikan antibiotik triple drug yaitu ceftriaxone, gentamisin, dan metronidazole ternyata hasil tes sensitifitas didapatkan bahwa gentamisin hanya sensitif pada kuman Streptococcus a hemolitikus, Klebsiella sp, dan Staphylococcus aureus sedangkan cefotaxime sensitif terhadap kuman Streptococcus a hemolitikus. ${ }^{13,15}$ Pendapat lain, Jeffrey dkk menyatakan preparat antibiotik yang umum digunakan untuk penderita abses leher dalam adalah 


\begin{tabular}{|c|c|c|c|c|c|c|c|c|c|}
\hline & $\begin{array}{c}\text { Strep. } \\
\text { pneumo } \\
\text { niae }\end{array}$ & $\begin{array}{c}\text { Strep. } \\
\text { aureus }\end{array}$ & $\begin{array}{c}\text { Strep. } \\
\text { a.hemo } \\
\text { litikus }\end{array}$ & Kleb.sp & $\begin{array}{c}\text { Stap. } \\
\text { aureus }\end{array}$ & E. colli & $\begin{array}{c}\text { Borre } \\
\text { lia } \\
\text { sp }\end{array}$ & $\begin{array}{c}\text { Ante } \\
\text { robacter } \\
\text { sp }\end{array}$ & $\begin{array}{c}\text { Pseudo. } \\
\text { aurigi } \\
\text { nosa }\end{array}$ \\
\hline Ampicillin & + & & & & & & & & \\
\hline Ampicilin-sulbac & + & & + & + & & + & & & \\
\hline Cefepime & + & + & + & + & & & & & \\
\hline Eritromisin & + & & + & & & & & & \\
\hline Meropenem & + & & + & + & + & + & & & + \\
\hline Moxifloksasin & + & & + & & & & & & \\
\hline Cefoperazone & + & & & & & + & & & \\
\hline Amikasin & & + & + & + & + & + & + & + & + \\
\hline Cefoxitin & & + & + & & + & & & & \\
\hline Ciprofloksasin & & + & + & + & + & & & & \\
\hline Kloramfenikol & & + & + & + & & & & & \\
\hline Ceftazidin & + & & & & & & & & \\
\hline Kotrimoksasol & & & + & + & & & & & \\
\hline Fosfomisin & & & + & + & & + & & & \\
\hline Gentamisin & & & + & + & + & & & & \\
\hline Amoksillin-klavu & & & + & & & & & & \\
\hline Cefotaxim & & & + & & & & & & \\
\hline Ceftriakson & + & & + & & & & & & \\
\hline Piper + tazobac & & & + & & & & & & \\
\hline Metronidazol & & & & + & & & & & \\
\hline Tetrasiklin & & & + & & & & & & \\
\hline Cefoperason & & & + & & & & & & \\
\hline Bacitrasin & & & + & & & & & & \\
\hline
\end{tabular}

ampisillin/sulbaktam, klindamisin, sefalosphorin generasi II (cefuroxime). ${ }^{6}$ Meher dkk mengemukakan untuk negara berkembang india, terapi empiris dengan penisilin, gentamisin dan metronidazol merupakan terapi yang efektif sebelum adanya hasil kultur dan tes sensitifitas. ${ }^{12}$ Yang dkk (2008) dalam penelitiannya pada pasien abses leher dalam A pril 2001 sampai Oktober 2006 di rumah sakit Chang Gung Memorial, didapatkan kultur bakteri dari 100 pasien memberikan hasil yang positif ( $89 \%$ ) bakteri aerob adalah Streptococcus viridans,
Klebsiella pneumoniae, dan Staphylococcus aureus. Bakteri anaerob yaitu Prevotella sp, Peptostreptococcus sp dan Bacteroides sp. Kombinasi antibiotik yang diberikan secara empiris penisilin G dan klindamisin $(67,4 \%)$, ceftriaxone dan klindamisin $(76,4 \%)$, ceftriaxone dan metronidazole $(70,8 \%)$, cefuroxime dan klindamisin $(61,8 \%)$, dan penisilin dan metronidazol $(16,9 \%){ }^{5}$ Kuriyama dkk dalam penelitiannya terhadap abses yang disebabkan odontogenik mengemukakan bahwa Streptococcus viridans peka terhadap penisilin (77\%), 


\begin{tabular}{|c|c|c|c|c|c|c|c|c|c|}
\hline \multicolumn{10}{|c|}{ Lokasi abses dan hasil kultur } \\
\hline & $\begin{array}{l}\text { Strep. } \\
\text { pneumo } \\
\text { niae }\end{array}$ & $\begin{array}{l}\text { Strep. } \\
\text { aureus }\end{array}$ & $\begin{array}{c}\text { Strep. } \\
\alpha . h e m o \\
\text { litikus }\end{array}$ & Kleb.sp & $\begin{array}{l}\text { Stap. } \\
\text { aureus }\end{array}$ & E. colli & $\begin{array}{c}\text { Borre } \\
\text { lia } \\
\text { sp }\end{array}$ & $\begin{array}{c}\text { Ante } \\
\text { robacter } \\
\text { sp }\end{array}$ & $\begin{array}{c}\text { Pseudo. } \\
\text { aurigi } \\
\text { nosa }\end{array}$ \\
\hline Abses submandi bula & + & + & & + & + & + & + & + & + \\
\hline Abses peritonsil & & & + & & + & & & & \\
\hline Abses sublingulis & \multicolumn{9}{|c|}{ Tidak ada pertumbuhan kuman } \\
\hline Abses retrofaring & \multicolumn{9}{|c|}{ Tidak diperiksa } \\
\hline Abses parafaring & \multicolumn{9}{|c|}{ Tidak diperiksa } \\
\hline
\end{tabular}

klindamisin (87\%), eritromisin (77\%), dan levofloksasin (92\%). Klindamisin dan levofloksasin juga sensitif terhadap kuman batang gram negatif anaerob karena tidak terpengaruh terhadap produksi $\beta$-laktam sehingga dapat direkomendasikan untuk penderita yang gagal diterapi antimikroba dengan antibiotik $\beta$-laktam. ${ }^{12,15}$ Kamath dkk (2003) menyatakan dari 29 pasien abses leher dalam, antibiotik yang diberikan pada 22 pasien yaitu kombinasi penicillin, gentamisin, dan metronidazole. Sebanyak 7 pasien mendapat kombinasi cefotaxime dan metronidazole. ${ }^{6}$

Penelitian ini didapatkan antibiotik yang paling sensitif terhadap sebagian besar hasil kultur adalah meropenem yang sensitif terhadap bakteri Staphylococcus aureus, Streptococcus pneumoniae, Streptococcus a hemolitikus, Klebsiella sp, dan E colli. Amikasin sensitif terhadap bakteri Staphylococcus aureus, Streptococcus aureus, Streptococcus a hemolitikus, Klebsiella sp, Borrelia sp, Anterobacter sp, E colli dan Pseudomonas auriginosa. Ciprofloksasin sensitif terhadap bakteri Staphylococcus aureus, Streptococcus aureus, Streptococcus a hemolitikus dan Klebsiella sp. Penelitian ini juga didapatkan sebagian besar diagnosis abses submandibula, dengan hasil kultur Staphylococcus aureus, Streptococcus pneumoniae, Streptococcus aureus, Klebsiella sp, Borrelia sp, Anterobacter sp, Pseudomonas auriginosa dan E colli. Berdasarkan hasil kultur dan tes sensitifitas, antibiotik yang dapat diberikan pada abses submandibula adalah meropenem, amikasin, atau kombinasi ampicillin subactam dengan ciprofloksasin. Diagnosis abses leher dalam terbanyak kedua adalah abses peritonsil dimana berdasarkan hasil kultur didapatkan kuman Streptococcus a hemolitikus dan Staphylococcus aureus, sensitif terhadap antibiotik meropenem, amikasin, cefoxitin, ciprofloksasin, atau gentamisin.

\section{SIMPULAN}

Abses leher dalam terbanyak adalah abses submandibula dengan etiologi infeksi odontogen dan Diabetes mellitus merupakan komorbid terbanyak. Rawat inap pasien rata rata $<7$ hari, 2 penderita meninggal karena adanya penyakit jantung dan sepsis. Hasil kultur bakteri yang tersering adalah Staphylococcus aureus, Klebsiella sp, Pseudomonas auriginosa, Streptococcus (aureus, pneumonia, a hemoliticus). Penatalaksanaan terpenting adalah insisi drainase disertai pemberian antibiotik yang sesuai dengan hasil kultur dan sensitivitas atau antibiotik drug of choise, berdasarkan bukti empiris penelitian ini adalah meropenem.

\section{DAFTAR PUSTAKA}

1. Soepardi E. A. dkk. Abses leher dalam, Dalam : Buku Ajar Ilmu Penyakit Telinga Hidung Tenggorok, Edisi 5 FKUI. 2011 : 1879.

2. Hibbert J. Tonsil and adenoid pediatric otolaryngology. In: Scoot Brown's Otolaryngology: Kerr AG, 5th ed London: Butterworth International editions; p.2008:368-81.

3. Ballenger JJ. Leher, orofaring dan nasofaring, Dalam: Penyakit Telinga Hidung Tenggorok Kepala dan Leher. Alih Bahasa : staf ahli bagian THT RSCM-FKUI. Edisi 13. Jilid 2. Binarupa Aksara. Jakarta 2010: 295-304.

4. Bailey BJ. Infections of the deep spaces of the Neck. Head and Neck Surgery Otolaryngology. 3 th Edition. Philadelphia. Wolters Kluwer Company. 2006. p.701-15.

5. Yang S-W, Lee M-H, See L-C, Huang S-H, Chen T-M, Chen TA. Deep neck abscess: an analysis of microbial etiology and the effectiveness of antibiotics. Infection and Drug Resistance. 2008;I:1-8.

6. Murray DA, MD. Deep neck infections. Mar 2008. [online] http:// www.emedicine.medscape.com/article/837048overview.

7. Coelho MS, Ramos G, Prestes LC, Soccol A, B MS, Lobo P. Deep neck infections - Classification in Levels of Severity. Intl Arch Otorhinolaryngol. 2009;13(2):184-8.

8. Rahmawati Novina, Suyitno Slamet. Penanganan abses submandibula di SMFK THT RSUP dr. Kariadi Semarang 
tahun 2003-2007. Kumpulan Naskah Ilmiah KONAS PERHATI. Bandung. 2008.

9. Federici S,Silva C,Maréchal C,Laporte E,Sévely A,routeau E,et al. Retro- and parapharyngeal infections: standardization of their management. Arch Pediatr. 2009;16(9):1225-32.

10. Chunduri NS, Madasu K, Goteki VR, Karpe T, Reddy H. Evaluation of bacterial spectrum of orofacial infections and their antibiotic susceptibility. Annals of Maxillofascial surgery. 2012;2(1):46-50.

11. Gonul O, Sertac A, Tulin S, Hasan G, Goker K, Odontogenik infection. A Textbook of Advanced Oral and Maxillofacial Surgery. InTech Pub.June; 2013. Chapter 3:315-366.

12. Neelam a, Swaran A, Vidya R, Anil K, Gauri P, Amit D et.al. Orofacial and neck infections and their management. Textbook of Oral and Maxillofacial Surgery 2nd Edition. Jaypee Brothers Medical Publisher Ltd. NewDelhi; 2008: p.587-635.
13. Hassan A, Seyyed MA, Hossein R, Faeze H, Ali G, Maliheh Y et al. Predisposising factors for the complication of deep neck infection. Iranian Journal of Otolarungology 2010; 22: 97-102.

14. David B. Ettinger MD, DMD. Management of odontogenic infections. [Online] http:// nnoha.org/nnohacontent/upload/2013/09/OralSurgery.

15. Geo F, Janet S, Stephen A. Jawetz, Melnick,\& Adelberg's. Medical microbiology, 23th ed. The McGraw-Hill Companies,Inc. 2007; 221-223. 